\title{
International Migration from Tonga, South Pacific: A Behavioral Approach
}

\author{
Raelyn Lolohea 'ESAU \\ Graduate Student, Department of Geography, Kyoto University, Kyoto 606-8501, Japan
}

\begin{abstract}
The purpose of this study is to examine socio-cultural aspects of international migration from Tonga and its impact based on the behavioral approach, which has thus far been neglected in existing literature associated with the country's migration. An interview and questionnaire survey of 150 households from the three island groups in Tonga was conducted. As a result, the following findings were obtained. Household size has recently decreased due to transformation from the extended family to the nuclear family and emigration from Tonga. Consequently, the number of migrants per household is larger than before. The individual or nuclear family rather than the extended family plays a greater role in migration decisionmaking now. With respect to the reason for migration, an increasing motivation to migrate for study abroad since the 1990s is remarkable. Reliance on remittance is not significant partially due to the increase in student migration. Furthermore, there is an obvious tendency for migrants to marry persons with Tongan nationality, and, thus, they are quite likely to settle in their host countries and not return to Tonga.
\end{abstract}

Key words: student migration, decision-making unit, remittance, dependency model, MIRAB model, Kingdom of Tonga

\section{Introduction}

International migration in the South Pacific region including Tonga began as a mere trickle in the early 1950s and eventually led to the dramatic outflow of people into the Pacific Rim countries of New Zealand, Australia and the United States in the 1960s and 1970s (Bedford and Lloyd 1982; Connell 1983a; Trlin 1987). The South Pacific region contains three indigenous population groups: Melanesia, ${ }^{1}$ Micronesia ${ }^{2}$ and Polynesia. ${ }^{3}$ The Melanesian islands have more than $75 \%$ of the population living in rural areas, but rural-urban migration is now conspicuous (Bedford 2002; Connell 1990). Fiji is an exception due to the political upheavals ensuing from the 1987 and 2000 coup d'etats, ${ }^{4}$ resulting in the dramatic emigration of the Indo-Fijian population (Bedford 1989; Chetty and Prasad 1993; Mohanty 2001). In contrast, the international migration of $\mathrm{Mi}$ cronesian and particularly Polynesian island countries is having a great impact on the home country population.

The remarkable diversity of the South Pacific region, coupled with the scattering of small islands of approximately $551,059 \mathrm{~km}^{2}$ across a vast ocean of 30 million $\mathrm{km}^{2}$, clearly makes the geographic distances between small island states within the region generally very great. As a result, these islands encounter 'special disadvantages associated with limited domestic markets, remoteness, a narrow resource base, indivisibilities in investment and proneness to natural disasters' (Cook and Kirkpatrick 1998: 845). The smallness of Pacific societies, however, does not imply that world development has been irrelevant to the region (Haberkorn 1997: 220).

The historical commencement of international migration from the Pacific Islands is greatly embedded in the colonial connections to the metropolitan countries (Appleyard and Stahl 1995; Brown 1998a; Connell 1990). This explains the diversification of emigration trends from various Pacific Island countries. For example, the Cook Islands, Niue and Tokelau became 'Island Territories' of New Zealand in the late 1940s (Hooper 1993), and it has given them the privilege of New Zealand citizenship by birthright (Connell 1990; Hooper 1993). The 
Western Samoans are granted citizenship for an annual quota of 1,100 by the New Zealand government (New Zealand Immigration 2002a).

Tonga is a unique case. Since the country was a British protectorate until 1970 (Campbell 2001) and lacked any political dependence with any Pacific Rim countries, it has often confronted various obstacles in obtaining visas to enter destination countries and international migration has became significant only in the 1970s (Hayes 1992; Connell 1990). Exceptional options associated with migration were through educational institutions and Christian churches (Bedford and Gibson 1986; Connell 1990; Hayes 1992). In addition, a temporary labor scheme to New Zealand was one way of facilitating the out-migration of unskilled workers from Samoa, Tonga and Fiji in the late 1970s (Bedford and Lloyd 1982; Bedford and Gibson 1986; Connell 1983b; Levick and Bedford 1988). This scheme was terminated in the 1980s due to labour market restructuring, which caused job losses in the manufacturing sector of New Zealand in the 1990s (Fletcher 1995; Statistics New Zealand 2002).

It is noteworthy that there are more Tongans living abroad than the home population. To date, the only available sources have been various population censuses of host countries because of the lack of a recording system in Tonga to monitor emigration, implying that the specific numbers are undocumented and mainly estimates (Connell 1983a). New Zealand is by far the most significant destination (Bedford and Gibson 1986; Trlin 1987; Brown 2002) for Tongan migrants. As of 1996, there are 40,716 in New Zealand (Statistics New Zealand 2001), 36,840 in the United States (United States Census Bureau 2001) and 8,430 in Australia (Fisi'iahi 2001). The New Zealand government recognizes the contributions made by the Pacific migrants to the country's economy and society (Brown 2002) and started Pacific Access Category (PAC) grants to 250 persons from Tonga, 75 persons from Tuvalu and 50 persons from Kiribati in 2002 (New Zealand Immigration 2002b). Table 1 illustrates the comparison of populations between the country of origin and New Zealand (Secretariat of the Pacific Community 2001).
Table 1. New Zealand census counts by Island population estimate

\begin{tabular}{lrr}
\hline Nationality & $\begin{array}{r}\text { New Zealand } \\
\text { census count }\end{array}$ & $\begin{array}{r}\text { Island population } \\
\text { estimate }\end{array}$ \\
\hline Samoan & 115,017 & 170,900 \\
Cook Islander & 52,569 & 19,300 \\
Tongan & 40,716 & 99,400 \\
Niuean & 20,148 & 1,900 \\
Tokelauan & 6,204 & 1,500 \\
Tuvalu Islander & 1,965 & 10,000 \\
\hline Total & 236,619 & 303,000 \\
\hline
\end{tabular}

Estimate at mid-2001 prepared by the South Pacific Commission Demographic/Population program.

Source: http://www.stats.govt.nz.

Organization of this paper is as follows. After a literature review on international migration focused on the South Pacific region, the aim of this article is presented. Next, the study area, Tonga, is briefly explained and the interview and questionnaire surveys are outlined. Then, the survey results are discussed by pointing to the significance of the obtained findings. Finally, concluding remarks are presented.

\section{Literature Review}

Previous studies on international migration of the South Pacific region produced two wellknown frameworks: the dependency model and Migration, Remittance, Aid and Bureaucracy (MIRAB) model (Hayes 1992). While the dependency model is derived from various country reports ${ }^{5}$ by Connell (1983a, b, 1987), the MIRAB model is from the joint study of Bertram and Watters $(1985,1986)$. Both models have the two constituents of the island (or internal) system and the international system. The former system consists of the three sub-systems: socio-cultural, demographic and economic. The latter system represents the connection between a particular country of the South Pacific and the destination countries, and has elements such as culture/education, aid, labor markets, trade and remittances.

The dependency model demonstrates the penetration of the global economy into the island economies and the transformation of the traditional value orientation and the aspiration of the islanders under consideration. According 
to the model, migration is encouraged by increasing aspirations for a satisfactory standard of living, desirable occupation and sufficient accessibility to various services including education and health (Connell 1983a, 1990). Consequently, there occurs a reduction both in the quality and quantity of the labour force in the island country through selective emigration of the educated or skilled and an influx of remittances from host countries. Noteworthy is that the dependency model lacks any equilibrating process, implying that the island population continues to decline (Hayes 1992).

In the meantime, the MIRAB model was made from the studies of the five small South Pacific countries of the Cook Islands, Niue, Tokelau, Tuvalu and Kiribati by using long-run statistical material. According to this model, a major motivation to migrate is the need to maximise income and to reduce labour surplus within the extended family unit (Bertram and Watters 1985, 1986). Ties and networks between the migrant and the remaining kin are strengthened by remittances and reciprocal visits, which further contribute to the making of a new trans-national corporation of kin. ${ }^{6}$ The MIRAB model assumes equilibrium in population change due to the constant exile of surplus labour, which leads to the constant flow of remittances into the islands. Population decline does not occur because out-migration is compensated for by high fertility.

According to an interesting and suggestive comparison by Hayes (1992), while the MIRAB model expects that migration is motivated by the kinship system, the dependency model lacks such an idea and attaches importance to the role of individualism derived from Western capitalism. A major contrasting difference between the two lies in view of the migration impact. The dependency model claims that migration fails to promote development in the islands and remittances foment economic inequality and dependence (Connell 1983a, 1983b, 1987, 1990). In contrast, the MIRAB model argues that island economies manage to be financially sustainable by the continuous emigration of surplus labour that could in turn guarantee the flow of remittance to the islands (Bertram and Watters 1985, 1986; Bertram
1986, 1993). With these contrasting points in mind, Hayes (1992) advocated an integrated model, which incorporates both the 'kinship system in conditioning migration decisions and the growing autonomy of individual family members from kin authority' (Hayes 1993a: 304). Much recently the MIRAB model has been subject to various reconsiderations (Bertram 1999; Poirine 1998).

I would like to devote attention to existing researches that have applied the two models to migration in the South Pacific region.

With respect to the dependency model, Va'a (1992) criticises the model's conclusion that migration should be discouraged and rural development should be encouraged (Connell 1983b). In addition, empirical studies show that severe adverse weather in Niue (Barker 2000) and a lack of human resources especially in the rural areas in Samoa (Muliana 2001) are chief push factors that encourage emigration. There have been fewer studies using or referring to the dependency model than the MIRAB counterpart so far.

The MIRAB model is commonly mentioned in many studies that emphasize the economic contribution of migrant remittances. Previous studies that examined the applicability of the MIRAB model to the Pacific islands include, for example, Fensterseifer (1993) on Western Samoa, Hayes (1993b) on Ware Island in Papua New Guinea, Hooper (1993) on Tokelau, Poirine (1994) on French Polynesia and comparative studies of various countries (Brown 1998a, b; Brown and Connell 2004; Connell and Conway 2000). However, McCall (1996, 1997), Hau'ofa (1993) and Laplagne (1997) criticize the continentalists' views of migration focused on the South Pacific islands as misinterpretation. Other studies include Cook and Kirkpatrick (1998) on Micronesia, Treadgold (1999) on Norfolk Island exemplifying the possibility of getting out of the MIRAB situation and the hopes of boosting agricultural yields and fisheries production to attain greater economic autonomy for Kiribati (Thomas 2002). Unfortunately, with respect to the integrated model developed by Hayes (1992), there has thus far been no detailed empirical investigation.

Next, let me devote attention to previous re- 
searches of migration associated with Tonga, the study country of this paper. Although Tonga was not included in the studies that resulted in the creation of the MIRAB model, the features of the model have affected Tonga in many ways. Especially notable is the increasing number of Tongans abroad (Bertram and Watters 1986) and the benefits of remittances and improvement of their social statuses $^{7}$ by an emerging middle class of welleducated commoners (Marcus 1974, 1981, 1993). Previous studies on Tonga (for example, Fuka 1984; Tongamoa 1987; Faeamani 1993, 1995) have emphasized the contribution of remittances to the household economy and to the development of Tonga. These studies concluded that the aspects of the MIRAB economy are inevitable, since there is high dependence on remittances. They argued that migration should be encouraged because it continues to be a success with the strong support of the kinship system. Outstanding remittances sent by migrants and the dominance of the government over aid (James 2002) enable us to classify Tonga as a typical MIRAB economy.

Hence, it can generally be mentioned that, as far as the migration of Tonga is concerned, the MIRAB model has attracted more attention and thus has tended to demonstrate higher explanatory power than the dependency model. Additionally, migration studies by anthropologists were ethnographies (James 1991; Small 1997; Sudo 1997; Morton 1998; Kishida 2000; Evans 2001).

In terms of the structure of the dependency model and the MIRAB model, mentioned earlier, existing studies of the migration of the South Pacific region including Tonga have given much attention to 'remittance' and 'aid' within the international system, 'migration' in the demographic sub-system and 'income' in the economic sub-system within the island system. On the other hand, however, the sociocultural sub-system has generally been overlooked in the existing literature. Particularly, although the 'motivation to migrate' forms an important element in the socio-cultural subsystem, it has been elucidated only partially. Furthermore, since both the dependency and the MIRAB models take a macro-level ap- proach, it is difficult for them to carefully examine the much smaller micro units, such as household and individual, which are actually involved in migration.

Hence, the purpose of this study is to examine socio-cultural aspects of international migration from Tonga and its impact based on the behavioral approach, which has thus far been neglected in existing literature associated with the country's migration. Specifically, questionnaire and interview survey on an individual/ household basis was utilized. As is well known, the behavioral approach in migration study is not new, having started in the 1960s (Boyle et al. 1998). Nevertheless, such an approach seems very useful and promising within the context of migration investigation for contemporary Tonga.

\section{The Study Area}

The study area is the Kingdom of Tonga, located in the South West Pacific within 15 and 23 degrees latitude South and 173 and 177 longitude West. Its population of 101,000 (Tonga Statistics Department 2001) inhabits about 36 of the 170 islands with a total land area of $744.34 \mathrm{~km}^{2}$. These islands are scattered along a sea area of $700,000 \mathrm{~km}^{2}$ and clustered into three main groups (Figure 1). The population density is 156 persons per $\mathrm{km}^{2}$, and the main island of Tongatapu houses $69 \%$ of the entire Tongan population. The country has a relatively large young population under the age of $15(39 \%)$. The census of Tonga shows a declining annual growth rate from 0.5\% (1976$1986)$ to $0.3 \%$ (1986-1996). A most notable change is the drastic decrease of population aged 15-34 in 1986-1996, mainly due to international migration (Tonga Statistics Department 1986, 1996).

Located just below the Tropic of Capricorn and west of the International Dateline, Tonga is 13 hours ahead of Greenwich Mean Time. Its west and north neighboring countries are Fiji and Western Samoa. The total land area is slightly larger than Amamiohshima Island (712 $\mathrm{km}^{2}$ ) of Kagoshima Prefecture, and the sea area is three times as wide as the area of Honshu Island. The smallness of Tonga can be under- 


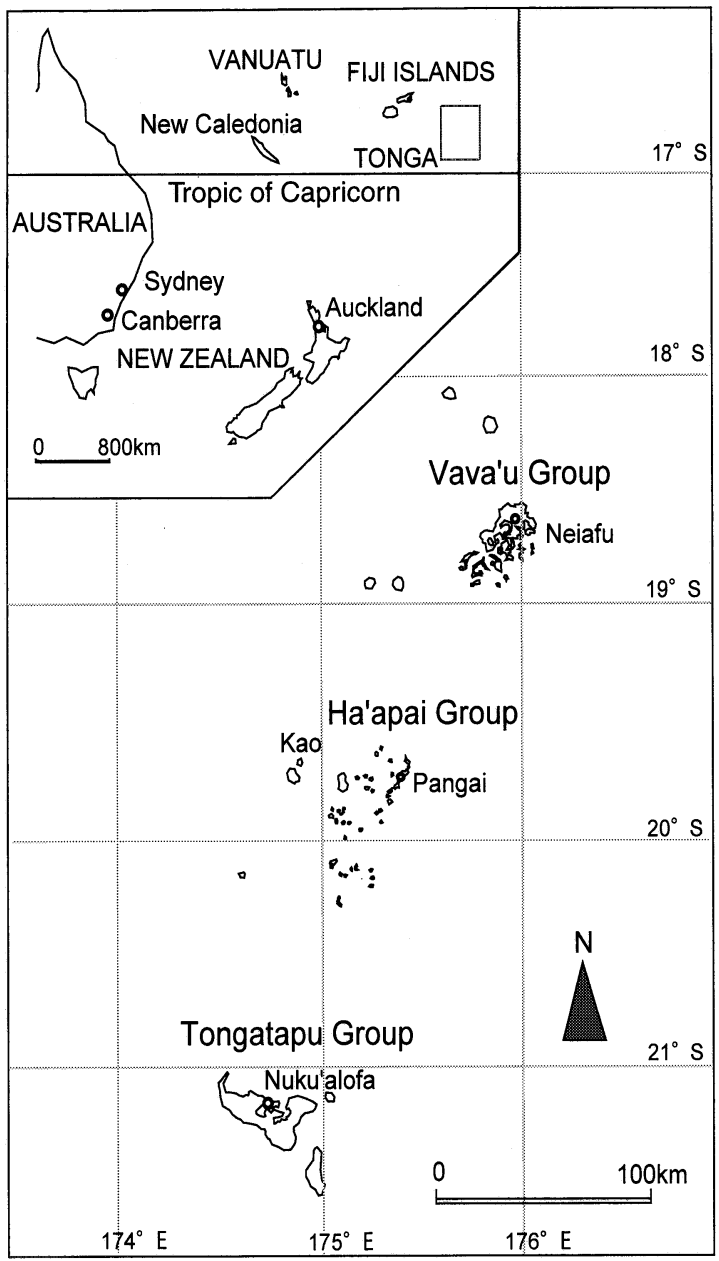

Figure 1. The map of the Kingdom of Tonga.

stood from these facts.

The three main island groups are Tongatapu, Ha'apai and Vava'u (see Figure 1). Tongatapu $\left(259 \mathrm{~km}^{2}\right)$ is the largest island, whose area is half of Awajishima Island, at 40 kilometers long and 20 kilometers wide, with its highest point at 82 meters. The Ha'apai group is comprised of small raised coral islands and atolls. Inclusive in this group is the volcanic island of Kao, which has the highest point ( 1,033 meters) in Tonga. The Vava'u group consists of one large raised coral island, which is higher on the southwestern side and rises to a height of 213 meters. The major natural resources in Tonga are the land, sea and its people; therefore, the yields from the land and the sea are the major contributors to the Tongan economy (Govern- ment of Tonga Official Website 2002).

The general household in Tonga has been said to be the extended family, which operates as a basic unit to fulfill socio-economic obligations and therefore plays an important role as the backbone of Tongan society (Vaden 1998). Nowadays, however, Tonga is undergoing family transformation from extended family to nuclear family and it is described in a detailed way in James (1991, 1998), Marcus (1993) and Morton (1996).

A major threat is the natural disaster of tropical cyclones, which hit Tonga annually, in combination with the country's relative smallness and isolation. Cyclones disadvantage the country in competing on an international level for promising trade markets. Hence, international migration is regarded as a safety valve (Connell 1983a, 1990; Appleyard and Stahl 1995), which implies safety measures for economies prone to instability and trade deficits.

Tonga's economy depends largely on agriculture products, forestry and fishery. These sectors constitute $28 \%$ of the real Gross Domestic Product (GDP) in 2001/02. Other major economic sectors are government services (18.5\%), finance, real estate and services (15.1\%), commerce, restaurant and hotel $(14.2 \%)$ and the official estimates for Tonga's real GDP growth rate is $0.5 \%$ in this fiscal year. Tonga suffers a very high inflation of $10.6 \%$. This inflation is due, first, to an increase in shipping freight costs, second, the weakening of the Tongan currency (pa'anga) against the United States dollar, Japanese yen and other major currencies, and, finally, the increase of imported goods prices twice or thrice in a year by overseas suppliers.

Tonga has a trade deficit. Large import items are consumer goods such as foodstuff and vehicles. In consideration of the impressive importation of vehicles to Tonga, a continual increase in fuel price is also a chief contributor to the deficit. The country fails to improve the trade balance since the level of exports cannot keep up with that of imports. Ironically, however, there is little effort made to encourage local production. New Zealand, Australia, the United States and Fiji are Tonga's major import partners (National Reserve Bank of Tonga 1999). 
Japan, which occupies about half of the total exports, is the largest export partner. The squash export to the Japanese market is a major export item, which nets around 4 to 13 million pa'anga per year (National Reserve Bank of Tonga 2000). The net trade balance for 2000/01 was -96.7 million pa'anga, which represents a deterioration of $38.1 \%$ from -70.0 million pa'anga in 1993/94.

Tonga receives support in aid from the European Union, New Zealand, Australia, Canada, Japan and other countries. The total grant from abroad, however, accounts for only $3.02 \%$ of the Tonga government total revenue for 2000/01 (Government of Tonga Budget Statement 2002). However, remittances constituted about $50 \%$ of the GDP in 2002 (Asian Development Bank 2003) and increased by $128.1 \%$ from 1994 to 2001 . They are the major contributors to Tonga's balance of payments (National Reserve Bank of Tonga 2000). Moreover, it is well known that these official figures of the transfer have underestimated the real amount of remittances that enter Tonga, because a large amount is considered to be through various unofficial channels ${ }^{8}$ (Brown 1994, 1995, 1997; Brown and Foster 1995).

\section{Interview and Questionnaire Survey}

The interview and questionnaire survey was conducted in Tonga during July and August 2002 for 150 households of the three groups of islands of Tongatapu (80 households), Ha'apai (20 households) and Vava'u (50 households). Sample households with migrants abroad were selected and information of 200 migrants was obtained from these households. Please note that information about emigrants from Tonga was collected not from the emigrants themselves, but through their family members staying in Tonga. It is not the best survey method; however, household members who were interviewed knew the emigrants very well. This method was inevitable in limited survey time. Worthy-of-note here is that a similar method was also used in James (1991), Faeamani (1993) and Evans (2001).

The "household" in this survey is defined here as people living in the same house. It is similar to the "household" definition in Tongan Census, namely, a group of persons living in the same village allotment (ideally 0.4 acres) regardless of the number of generations therein. Such group can constitute not only nuclear family but also extended family; actually, about twothirds of the sampled households in my survey are nuclear families and the rest are extended families. Based on such definition of "household," transformation from extended family to nuclear family in the country has been described in previous studies (James 1991, 1998; Marcus 1993; Morton 1996).

A certain part of the sample households in this survey has plural migrants per household. This is because there is an increasing tendency of emigration from Tonga in recent years and it is not unusual for a particular household to have two or more emigrants, although each household had only one emigrant previously. Regarding the household which has two or more emigrants, the first person who emigrated from it was selected. In the data analyses including figure and tables, 150 households were used for investigation associated with household, and 200 migrants were used for investigation associated with migrants themselves.

The samples taken from Tongatapu were selected from the four main districts (Greater Nuku'alofa, Central, Eastern and Western District). Each district has about 15 to 20 villages. Fortunately, the district officers assisted me in identifying households with migrants abroad. ${ }^{9}$ Two or three households were selected from each village on average. The two outer islands of Ha'apai and Vava'u were also included in the survey to examine differences among the major islands. In these two islands, the survey was attempted only in the principal districts, and five households per village on average were selected from an identified list of families with migrants abroad, based on the author's preliminary investigation.

I gave informal interviews using a prepared questionnaire sheet to obtain information about the migrants' decision-making and migration impact. With reference to the households recorded in the 1996 population census of Tonga, the sample households covered $0.74 \%$, $1.36 \%$ and $1.83 \%$ of Tongatapu, Ha'apai and 
Vava'u, respectively (Tonga Statistics Department 1996). About 25\% of the migrants in this survey visited Tonga during the period of my survey, due to various church conferences and family events, which enabled the author to interview them personally. Migrants with email addresses were later contacted for confirmation of information obtained from their families in Tonga. The data obtained from this survey were analyzed using SPSS (version 10.0).

\section{Results and Discussions}

Major findings obtained from the interview and questionnaire survey are explained below based on figures and tables. Then, implications for existing literature are discussed.

Table 2 is a summary of selected characteristics of the households and the migrants under analyses. While the items of "gender of migrants abroad" and "kindred of household members currently abroad" concern the migrants, those of "household size," "household members currently abroad" and "pattern of per household migrants abroad" concern the households. The migrants are predominantly 'male' and 'son' or 'daughter.' Meanwhile, the households are predominantly smaller in size, ' $4-6$ persons' or ' $1-3$ person' in terms of "household size," '1 person' and ' 2 persons' in terms of "household members currently abroad," and ' 1 migrant only abroad' and ' 2 or more migrants in the same destination' in terms of "pattern of per household migrants abroad." Table 2 indicates a smaller household size in comparison with six persons per household on average according to the 1996 population census (Tonga Statistics Department 1999) and suggests an increasing tendency for households to have two or more migrants currently abroad. These findings seem to imply an intensification of emigration from Tonga under way.

Figure 2 illustrates the trend of emigration from Tonga during the past four decades based on the questionnaire survey. The return migrants from overseas are not included and the comprehensive data for emigration from Tonga is not available due to the absence of a departure card recording system by Immigration Department of Tonga. It shows a gradual increase of departures since the 1970s. In spite of annual fluctuation, more than ten emigrations are observed annually in recent years. Whereas the emigration in the 1980s generally arose from

Table 2. Summary of respondents and the migrants abroad

\begin{tabular}{llrr}
\hline Gender of migrants abroad & Male & 110 & $(55)$ \\
& Female & 90 & $(45)$ \\
\hline Residental Island & Tongatapu & 80 & $(53)$ \\
& Ha'apai & 20 & $(13)$ \\
& Vava'u & 50 & $(34)$ \\
\hline Kindred of houshold members & Parents & 46 & $(23)$ \\
currently abroad & Son & 87 & $(44)$ \\
& Daughter & 67 & $(33)$ \\
\hline Household size & $1-3$ persons & 69 & $(46)$ \\
& $4-6$ persons & 76 & $(51)$ \\
& $7+$ persons & 5 & $(3)$ \\
\hline Household members currently & 1 person & 63 & $(42)$ \\
abroad & 2 persons & 46 & $(31)$ \\
& $3-4$ persons & 33 & $(22)$ \\
& $5+$ persons & 8 & $(5)$ \\
\hline Pattern of per household & 1 migrant only abroad & 63 & $(42)$ \\
migrants abroad & 2 or more migrants in the same destination & 55 & $(37)$ \\
& 2 or more migrants in different destinations & 32 & $(21)$ \\
\hline
\end{tabular}

Note: The figures in parentheses imply percentage.

Source: The author's questionnaire survey. 


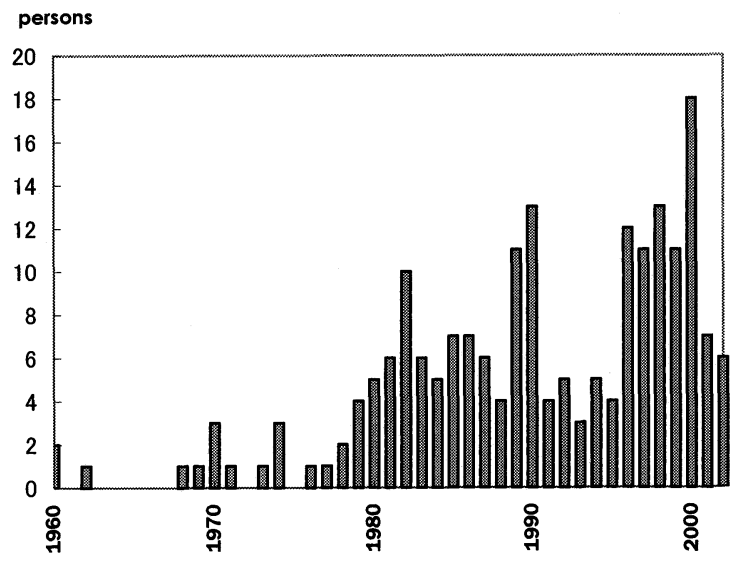

Figure 2. Emigration from Tonga based on the questionnaire survey.

Note: The return migrants from overseas are not included and the data for general emigration from Tonga is not available due to the absence of a departure card recording system by the Immigration department of Tonga.

Source: The author's questionnaire survey.

the flexible immigration regulations of destination countries, emigration in the 1990s was largely characterized by student migration and family reunions.

Figure 3 illustrates the initial motivation to migrate obtained from the data the author collected. 'Study abroad' and 'job' constitute the two largest categories, which together form approximately two-thirds of all migrants. The highest rate of 'study abroad' is mainly due to the shortage of post-secondary education institutions within Tonga.

Table 3 reveals the relationship between "means of financing" for migration and the "migration decision-making unit." Regarding

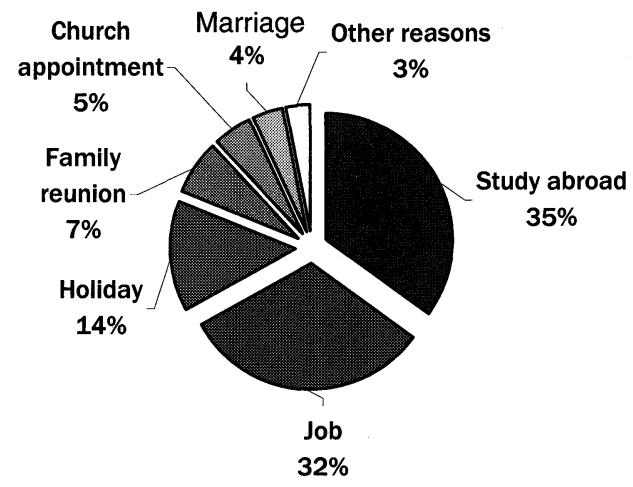

Figure 3. Initial motivation to migrate. Source: The author's questionnaire survey.

"means of financing," the family's role, shown in 'family overseas' (32\%) and 'family in Tonga' $(25 \%)$, and the economic independence of migrants shown in 'own money' (18\%) are conspicuous. With respect to the decision-making unit associated with emigration, 'nuclear family' of emigrants forms the largest share (65\%), followed by 'individual' (31\%); meanwhile, the share of 'extended family' (4\%) is negligible. It could be implied that there is a declining authority of the 'extended family' in the migration decision making process. It has also been mentioned elsewhere (James 1991; Morton 1996) that the decision making of an extended family tends to be limited to ceremonial occasions, while the decision to migrate is becoming atomized.

Figure 4 denotes the relationship between "household income" and "return visit frequency." Generally, the frequency depends

Table 3. Means of financing and migration decision-making unit

\begin{tabular}{lccccc}
\hline \multicolumn{1}{c}{ Means of financing } & Individual & Nuclear family & Extended family & \multicolumn{2}{c}{ Total } \\
\hline Loan & 4 & 11 & 1 & 16 & $(8)$ \\
Family in Tonga & 8 & 40 & 1 & $49(25)$ \\
Family overseas & 18 & 40 & 6 & $64(32)$ \\
Scholarship & 14 & 4 & 0 & 18 & $(9)$ \\
Employer overseas & 3 & 8 & 0 & 11 & $(5)$ \\
Own money & 12 & 23 & 1 & $36(18)$ \\
Other & 2 & 4 & 0 & 6 & $(3)$ \\
\hline Total & $61(31)$ & $130(65)$ & $9(4)$ & $200(100)$ \\
\hline
\end{tabular}

Note: The figures in parentheses imply percentage.

Source: The author's questionnaire survey. 


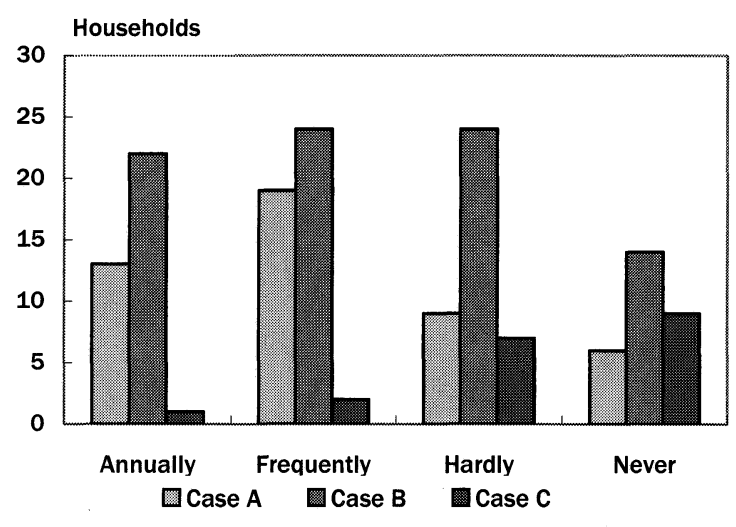

Figure 4. Relationship between household income and the return visit frequency.

Note: 1) Case A: low income and high remittance, Case B: high income and low remittance, Case C: high income and no remittance. There are no cases of the three categories 'low income and no remittance,' 'low income and low remittance' and 'high income and high remittance.' The terms 'high' and 'low' here denote annual income of more than, and less than 10,000 pa'anga, respectively. The total income was only cash income quoted by the respondents.

2) 'Frequently' denotes return once in every 2-5 years and 'hardly' denotes return once every 6 10 years.

Source: The author's questionnaire survey.

upon factors such as the visa type, economic affordability and social status of migrants abroad. Please note that the term 'household income' does not contain remittances. Although I was able to obtain income information for each of the households under consideration from the interview, the exact amount of the remittances for each of them was unobtainable. Thus, to anticipate a relative weight of remittance and to discuss its relation with the returnto-visit frequency, I have to use the criterion, based on the answer in the survey, as to whether the remittance is larger than the income, and, finally, classify all households into three groups (Cases A, B and C). The weight of remittance in the household economy decreases from Case A, to Case B to Case C in this order.

Figure 4 suggests that the contribution of remittance to the household economy is not significant, because Case $\mathrm{B}$ and Case $\mathrm{C}$ constitute approximately two-thirds of all households. Moreover, a great difference among these three cases can, to a certain extent, be explained in terms of the migration time and the motivation to migrate.

A great majority of Case A consists of migration that aimed at a 'job' overseas and occurred in the recent period, since the 1990s. The dominance of 'annually' and 'frequently' is related to the attendance of church activities and family obligations in Tonga. With regard to other notable migrants contained in this case, the difficulty of obtaining a permanent visa, especially for those in the United States, needs to be mentioned. These emigrants have to continually renew their short-term visas in order to maintain their jobs and continue remitting to their families. ${ }^{10}$

Typical migrants of Case B are those who left Tonga to 'study abroad' in the 1990s and find a 'job' in the decades of the 1970s and 1980s. Although this case forms the largest share of all households, there is no significant difference in shares of 'annually,' 'frequently' and 'hardly.' Thus, a convincing explanation for the relationship between household income and return visit frequency is difficult.

Regarding Case $\mathrm{C}$ with no remittance, there is a tendency for return visits to be 'never' or 'hardly,' although the number of these cases is relatively small. Case $\mathrm{C}$ is mostly formed by the motivations 'study abroad' in the past 5 years and 'job' in the 1970s. The low frequency of the latter migrants seems to arise from a developing social network and an increasing will to settle for a longer duration in the host countries.

Table 4 explores remittance uses. To compare the findings here with those in previous studies, investigations by Tongamoa (1987) and Faeamani (1993) are referred to as well. According to my survey, 'daily consumption' $(35 \%)$ and 'household bills' (21\%) constitute major uses, and 'church' and 'education fees' follow. Meanwhile, Tongamoa (1987) indicates that 'daily consumption,' 'church' and 'educational fees' are the three most important uses on a multi-answer basis; Faeamani (1993) clarifies that the remittance uses of 'church,' 'daily consumption' and 'household bills' are important. The results of the three studies including my survey, shown in Table 4, are greatly different from each other. Since such difference may arise from differences of year, place and respon- 
Table 4. Remittance uses in three migration surveys on Tonga

\begin{tabular}{lrrr}
\hline Remittance uses & $\begin{array}{c}\text { Tongamoa } \\
(1987) \%\end{array}$ & $\begin{array}{c}\text { Faeamani } \\
(1993) \%\end{array}$ & $\begin{array}{c}\text { 'Esau* } \\
(2002) \%\end{array}$ \\
\hline Daily consumption & 84 & 17 & 35 \\
Church & 71 & 21 & 18 \\
Education fees & 56 & 8 & 12 \\
Household bills & - & 12 & 21 \\
House construction & 9 & 5 & 7 \\
Other & 2 & 37 & 7 \\
\hline Total & 222 & 100 & 100 \\
\hline
\end{tabular}

Source: Tongamoa 1987: 106; Faeamani 1993: 112; and * present study.

Note: 1) Information only for main uses of remittances is presented.

2) 'Household bills' refers to the water, electricity and gas payments.

3) Tongamoa's survey permits multiple-answer way, implying 'total' exceeds $100 \%$.

dents of the survey, it is difficult to extract a general tendency from them.

Table 5 shows the results of "destination country," "communication method" and "nationality of migrant's spouse." The total number (109 persons) of "nationality of migrant's spouse" means that the other migrants are single. Since the strength of the social network between particular origin-destination pairs through chain migration is well known, the data for the major islands are also presented here. Regarding "destination country," New Zealand, the United States and Australia are popular, in this order. In Ha'apai, however, emigration to New Zealand is exceptionally rare (only one person), although the reason is unclear. Rather traditional methods such as 'telephone only' or 'telephone and postal mail' are the dominant means of communication between the migrants and their family members in Tonga. With respect to "nationality of migrant's spouse," 'Tongan' is quite large (69\%) and there is an obvious tendency for Tongan migrants abroad to marry within the same nationality. The nationalities 'American,' 'Australian' and 'New Zealander' have only 21\%, but the most popular nationality among these three countries is 'American,' implying a slight difference of order in terms of "destination country" and "nationality of migrant's spouse."

Table 6 illustrates the relationship between the reason for and duration of the return visit to Tonga. Significant reasons for migrants to return are 'family matters' and 'church activities,' and the most remarkable duration is ' 1 month.' Some explanation is needed about 'annual conference' in 'church activities.' It lasts for about a week and the main agenda for discussion cover the maintenance of church infrastructure, clergymen reshuffling, progress of church-owned schools, decision of the next con-

Table 5. Destination country, communication method and nationality of migrant's spouse

\begin{tabular}{|c|c|c|c|c|c|}
\hline & & Tongatapu & Ha'apai & Vava'u & Total \\
\hline \multirow{5}{*}{ Destination country } & New Zealand & 38 & 1 & 21 & $60 \quad(40)$ \\
\hline & Australia & 14 & 8 & 5 & $27 \quad(18)$ \\
\hline & United States & 20 & 6 & 17 & $43 \quad(27)$ \\
\hline & Other & 8 & 5 & 7 & $20 \quad(13)$ \\
\hline & Total & 80 & 20 & 50 & $150(100)$ \\
\hline \multirow{4}{*}{$\begin{array}{l}\text { Communication } \\
\text { method }\end{array}$} & Telephone only & 46 & 14 & 14 & $74 \quad(49)$ \\
\hline & Tel \& postal mail & 20 & 5 & 29 & $54 \quad(36)$ \\
\hline & Tel/postal mail/email & 14 & 1 & 7 & 22 (15) \\
\hline & Total & 80 & 20 & 50 & $150(100)$ \\
\hline \multirow{6}{*}{$\begin{array}{l}\text { Nationality of } \\
\text { migrant's spouse }\end{array}$} & Tongan & 48 & 8 & 19 & $75 \quad(69)$ \\
\hline & American & 5 & 2 & 5 & 12 (11) \\
\hline & Australian & 3 & 2 & 2 & $7 \quad(6)$ \\
\hline & New Zealander & 1 & 0 & 3 & $4 \quad(4)$ \\
\hline & Other & 3 & 4 & 4 & $11 \quad(10)$ \\
\hline & Total & 60 & 15 & 33 & $109(100)$ \\
\hline
\end{tabular}

Note: The figures in parentheses imply percentage.

Source: The author's questionnaire survey. 
Table 6. Reason for return trip and its duration

\begin{tabular}{lccccc}
\hline Return visit & 2 weeks or less & 1 month & 2 months & 3 months or more & Total \\
\hline Family matters & 5 & 42 & 8 & 2 & 57 \\
Church activities & 6 & 28 & 3 & 2 & $39(56)$ \\
House building & 2 & 5 & 2 & 3 & $12(11)$ \\
\hline Total & 13 & 75 & 13 & 7 & $108(100)$ \\
\hline
\end{tabular}

Note: 1) 'Family matters' refer to birth, weddings, funerals, and reunions. 'Church activities' refer to annual conferences and inauguration of church property.

2) Figures in parentheses imply percentage.

Source: The author's questionnaire survey.

Table 7. Transition of marital status of migrants

\begin{tabular}{l|ccccc|rr}
\hline before & Single & Married & Divorced & Remarried & Widowed & \multicolumn{2}{|c}{ Total } \\
\hline Single & 58 & 73 & 0 & 2 & 0 & 133 & $(66.5)$ \\
Married & 0 & 57 & 0 & 5 & 0 & 62 & $(31)$ \\
Divorced & 0 & 0 & 2 & 2 & 0 & 4 & $(2)$ \\
Remarried & 0 & 0 & 0 & 0 & 0 & 0 & $(0)$ \\
Widowed & 0 & 0 & 0 & 0 & 1 & 1 & $(0.5)$ \\
\hline Total & $58(29)$ & $130(65)$ & $2(1)$ & $9(4.5)$ & $1(0.5)$ & $200(100)$ \\
\hline
\end{tabular}

Note: The figures in parentheses imply percentage.

Source: The author's questionnaire survey.

ference venue and so on. Table 6 signifies that church-related activities form a very important element in Tonga's contemporary sociocultural life. 'House building' is also significant due to the damages of the tropical cyclone waka. This factor is especially considerable for migrants from Vava'u Island, because cyclones raged in the northern islands of Tonga during the first half of 2002 .

Table 7 shows the transition of the migrants' marital status before and after migration from Tonga to foreign countries. Two-thirds of the migrants (133 persons), half of whom are formed by students, left Tonga as 'single.' More than half of them (73 persons) married after migration, although the status of the great majority (118 migrants) remained unchanged. Worthy-of-note is the change of marital status from 'single' to 'married,' implying the making of new ties in the host countries.

Figure 5 depicts the relationship between the current visa status of migrants and their likelihood of return to Tonga. It is very obvious that the migrants with rights of 'permanent residency' or 'citizenship' have a definite will to settle in the host country. The migrants with a 'temporary visa' are likely to return to Tonga once their visas expire. However, half of these migrants are positive as to extending their stay abroad, and, ultimately, to continue living there permanently, if possible. In addition, there is hardly any indication that migrants in the host countries will return even when they retire

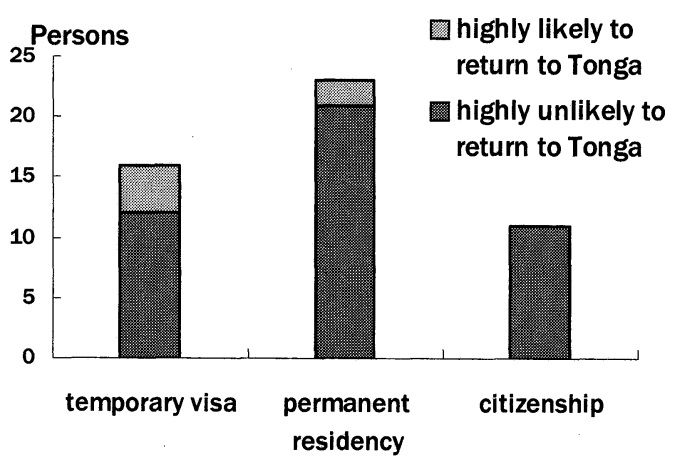

Figure 5. Current visa statuses of migrants and the likelihood of return to Tonga.

Note: 'Permanent residency' and 'citizenship' imply the visa statuses acquired from the destination countries after a period of residency.

Source: The author's questionnaire survey. 
from their present occupations.

Next, keeping the existing studies in mind, I would like to refer to the significance of the findings obtained here and their implications.

First, household size has been reduced recently for two reasons: transformation from extended family to nuclear family and emigration from Tonga. As a consequence, the number of migrants per household is now larger than the ones previously. This can be confirmed from Tonga's population censuses and similar findings are described in Tongamoa (1987), James (1991), Faeamani (1993) and Morton (1996). Moreover, according to my survey, most households can afford the cost of migration to travel abroad. This finding contrasts with Connell (1990), who indicated that migration is selective and limited to the highly educated and skilled.

Second, my finding that the individual or nuclear family rather than the extended family plays a greater role in migration decisionmaking is notable. A prominent role taken by the extended family is a major characteristic of the MIRAB model. Given the traditional Tongan way of thinking associated with migration, such a trend is new. It has also been reported elsewhere (James 1991; Morton 1996) that the decision making of an extended family tends to be limited to ceremonial occasions, while the decision to migrate is becoming atomized. This finding including mine is contrary to the MIRAB model (Bertram and Watters 1985) and seems to support the dependency model (Connell 1990), which demonstrates an important role of individualism. Furthermore, based on such a perspective, strong communication networks currently observed may not necessarily lead to longevity of reciprocity between Tonga and the migrants in the host countries.

Third, an increasing motivation to migrate for study abroad during the past decade is clarified, but it has seldom been mentioned in previous studies of migration focused on Tonga. This is related to a high rate $(73$ migrants, or more than one-third of all migrants) of marital status change from 'single' to 'married' after migration. Quite noteworthy is that the traditional motivation of 'job,' which has attracted great attention in existing literature on international migration, ranks second.
Fourth, according to my survey, reliance on remittance is not significant partially due to an increasing share of student migration. This finding contrasts with previous studies, which demonstrate a strong dependence on remittance (e.g., Fuka 1984; Tongamoa 1987; Faeamani 1993). There has been an interesting debate as to whether remittances were used either negatively (for example, daily life consumption and house building/repair) or positively for future development (for example, investment and savings), as shown in Fuka (1984), Tongamoa (1987) and Faeamani $(1993,1995)$. Although I cannot answer this question convincingly based on my survey, a certain use of remittance for education fees, which I have elucidated here, seems to serve as evidence that the remittances have partially been directed to positive purposes for future development. An increasing motivation to emigrate for the purpose of study abroad is noticeable, but it does not mean that remittance has been losing its role. However, it is still important particularly for households, which have to depend upon it.

Fifth, although a change in the migrants' marital status in host countries and its implications have hardly been discussed in existing researches associated with migration from Tonga, I have presented the finding that there is an obvious tendency for migrants to marry persons with Tongan nationality. While this may contribute to the persistence of migrant ties with Tonga, it can lead them to develop a new social network within the host countries. The latter view seems to explain other findings in this paper, or a less remarkable role of remittance and a marked likelihood not to return to Tonga among the migrants. It remains unknown, however, whether the fact that emigrants from Tonga get married with persons of Tongan nationality and develop a new social network in the host countries will lead to a possibility that the ties with Tonga and their families decline or to another possibility that it will help to construct a new transnational network including Tonga. This topic needs to be examined carefully on a long-term basis hereafter. 


\section{Conclusions}

The purpose of this study was to examine socio-cultural aspects of international migration from Tonga and its impact based on the behavioral approach, which has thus far been neglected in existing literature associated with the country's migration. An interview and questionnaire survey of 150 households from the three island groups in Tonga was conducted. The major findings obtained are as follows.

The number of migrants per household is larger than before partially due to emigration from Tonga. The individual or nuclear family rather than the extended family plays a greater role in migration decision-making now. With respect to the reason for migration, an increasing motivation to migrate for study abroad since the 1990 s is remarkable. Reliance on remittance is not significant partially due to the increase of student migration. Furthermore, there is an obvious tendency for migrants to marry persons with Tongan nationality, and, thus, they are quite likely to settle in their host countries and not return to Tonga.

The specific implications of the findings obtained here for existing studies are already discussed carefully in the preceding section. Thus, I would like to mention a general comment on the two well-known models, the dependency model and the MIRAB model. They were born within the context of survey reports for several countries in the South Pacific region. Although the two models have exerted great influence on migration studies in this region and I have learned a lot from them, the results of this paper do not support one of the two models exclusively. Because the models were made by incorporating circumstances and conditions before the 1980 s, we should now attach importance to more recent factors such as an increasing amount of student migration.

Finally, a few problems of this paper need to be mentioned. Because a survey of emigrants dispersed in several host countries was quite difficult, a survey of households that have emigrants from Tonga and live in the country was inevitably attempted. In other words, an inter- view or questionnaire of the emigrants themselves was not conducted here. As a result, important in-depth information including the migrants' actual legal status, their social network and their will to return/settle could not be collected. In addition, since this article adopts the behavioral approach mainly on a migrant/household basis, macro-level factors, such as political and economic relationships between Tonga and host countries and the government immigration policies of the host countries, are mentioned only partially. How the recent changes in the socio-cultural system, clarified in this study, have affected the demographic and economic sub-systems of the island system is another important topic. However, these issues belong to future research agenda.

\section{Acknowledgments}

This paper is based on a master's thesis submitted to the Graduate School of Human and Natural Environment Sciences, the University of Tokushima, in February 2003. I acknowledge the scholarship from the Government of Japan, which enabled this study. The author is immensely indebted to Professor Hirai Shogo of the University of Tokushima for his invaluable supervision and support during the progress of this study. In addition, I extend my sincere thanks to Associate Professor Toyoda Tetsuya, Associate Professor Takahashi Shin'ichi and Lecturer Higuchi Naoto of the University of Tokushima. Moreover, I would like to show my appreciation for the kindness shown to me by all of the 150 households, related organizations, individuals and the family of the author in Tonga. Finally, the author is indebted to Professor Ishikawa Yoshitaka of Kyoto University for his professional advice and comments on the earlier draft of the article.

(Received 15 July 2003) (Accepted 20 February 2004)

\section{Notes}

1. Solomon Islands, Vanuatu, Papua New Guinea, Fiji and New Caledonia.

2. Kiribati, Federate States of Micronesia, Nauru, Mariana, Guam, Marshall Islands and Palau.

3. Cook Islands, Niue, French Polynesia, Western Samoa, American Samoa, Tokelau, Tuvalu, Wallis and Futuna, Pitcairn and Tonga.

4. Fiji experienced a coup d'etat twice due to political and constitutional crisis resulting in the overthrow of a democratically elected government by military force in 1987 and by civilian 
minority in 2000 .

5. A major research project undertaken by John Connell producing country reports on migration, employment and development in the South Pacific on behalf of the South Pacific Commission (SPC) Research, which covered 24 countries. The project was sponsored by the United National Fund for Population Activities (UNFPA), published by the SPC Noumea, New Caledonia.

6. It allows the kin members to take advantage of the economic opportunities available from the international migration of members.

7. The social stratification in Tonga is based on three main groups, with the Royal family at the summit, the nobility and the commoners, which contains about $98 \%$ of the population. The commoners are restricted to this social status and there is no upward mobility since the upper classes are hereditary.

8. Like in Brown (1994: 353), unofficial forms of remittances or correspondences to them in my investigation include money sent delivered by mail or by hand, goods sent, money carried by the migrant, goods carried by the migrant, payments made by the migrant on behalf of a family member, gifts in the form of air fares and board and lodging for overseas visits by family or others to visit the migrant.

9. District officers are nominated as representatives of the government for districts which consist of 15-20 villages. Usually the 'district officer' post is passed on from father to son; hence they have a very good knowledge of their respective districts. The assistance from the officers was very helpful, but the sampling method assisted by them may be biased. This was inevitable in limited survey time.

10. Noteworthy in this present study is that, while regular remittances are not significant, irregular remittances are still significant; This differs from previous findings (Tongamoa 1987; Faeamani 1993) that show remittances were highly regular and seldom requested by the recipients. The occasional remittances for such events appear to confirm the tie of extended families, but its importance seems to be declining.

\section{References}

Appleyard, R. T., and Stahl, C. W. 1995. South Pacific migration: New Zealand experience and implications for Australia. International Development Issues no. 42, Australian Agency for International Development (AusAid). Canberra: CPN Publications.

Asian Development Bank. 2003. Economic trends and prospects in developing Asia. Asian Development Outlook 2003: Tonga. 194-196. Asian Develop- ment Bank.

Barker, J. C. 2000. Hurricanes and socio-economic development on Niue island. Asia Pacific Viewpoint 41(2): 191-205.

Bedford, R. 2002. Perspectives on population growth, migration and sustainable development in the Pacific region. In $5^{\text {th }}$ International APMRN Conference, Fiji 2002: Selected Papers, ed. K. Lyon and C. Voigt-Graft, 7-20. Working paper no. 12. Asia Pacific Migration Research Network, CAPSTRANS, University of Wollongong.

Bedford, R. 1989. Out of Fiji: A perspective on immigration after the coups. Pacific Viewpoint 30(2): 142-153.

Bedford, R. D., and Gibson, K. 1986. Migration, employment and development in the south Pacific, Country report no. 23B New Zealand. Noumea, New Caledonia: South Pacific Commission and International Labour Organisation.

Bedford, R. D., and Lloyd, G. 1982. Migration between Polynesia and New Zealand 1971-1981: Who are the migrants? New Zealand Population Review 1 (1): 35-43.

Bertram, G. 1986. Sustainable development in Pacific micro-economies. World Development 14(7): 809822 .

Bertram, G. 1993. Sustainability, aid, and material welfare in small south Pacific island economies, 1900-90. World Development 21(2): 247-258.

Bertram, G. 1999. The MIRAB model twelve years on. The Contemporary Pacific 11(1): 105-138.

Bertram, I. G., and Watters, R.F. 1985. The MIRAB economy in south Pacific microstates. Pacific Viewpoint 26(3): 497-519.

Bertram, I. G., and Watters, R.F. 1986. The MIRAB process: Earlier analyses in context. Pacific Viewpoint 27(1): 47-59.

Boyle, P., Halfacree, K., and Robinson, V. 1998. Exploring contemporary migration. New York: Addison Wesley Longman Limited.

Brown, R. 2002. In personal communication. Manager for immigration services, Tonga Branch. 6 August, Nuku'alofa.

Brown, R. P. C. 1994. Migrants' remittances, savings and investment in the south Pacific. International Labour Review 133(3): 347-367.

Brown, R. P. C. 1995. Hidden foreign exchange flows: Estimating unofficial remittances to Tonga and Western Samoa. Asian and Pacific Migration Journal 4(1): 35-54.

Brown, R.P.C. 1997. Estimating remittance functions for Pacific island migrants. World Development 25(4): 613-626.

Brown, R. P. C. 1998a. Do migrant's remittances decline over time? Evidence from Tongans and Western Samoans in Australia. The Contemporary Pacific 10(1): 107-151.

Brown, R. P. C. 1998b. Comparative labor market performance of visaed and non-visaed migrants: 
Pacific islanders in Sydney. Journal of Population Economics 11: 395-411.

Brown, R. P. C., and Connell, J. 2004. The migration of doctors and nurses from South Pacific islands nations. Social Science and Medicine. In press.

Brown, R. P. C., and Foster, J. 1995. Some common fallacies about migrants' remittances in the south Pacific: Lessons from Tongan and Western Samoan research. Pacific Viewpoint 36(1): 29-45.

Campbell, I. C. 2001. Island Kingdom: Tonga ancient and modern. 2nd ed. Christchurch: Canturbury University Press.

Chetty, N. K., and Prasad, S. 1993. Fiji's emigration: An examination of contemporary trends and issues. Demographic report 4. Suva: University of the South Pacific, School of Social Economic Development.

Cook, P., and Kirkpatrick, C. 1998. Labor market adjustment in small open economies: The case of Micronesia. World Development 26(5): 845-855.

Connell, J. 1983a. Migration, employment and development in the south Pacific. Country report no. 18, Tonga. Noumea, New Caledonia: South Pacific Commission and International Labour Organization.

Connell, J. 1983b. Migration, employment and development in the south Pacific. Country report no.22. Samoa. Noumea, New Caledonia: South Pacific Commission and International labour organization.

Connell, J. 1987. Paradise left? Pacific islands, voyagers in the modern world. In Pacific bridges: The new immigration from Asia and the Pacific islands, ed. J. T. Fawcett and B. V. Carino. New York: Center for Migration Studies.

Connell, J. 1990. Modernity and its discontents: migration changes in the south Pacific. In Migration, employment and development in the south $\mathrm{Pa}$ cific, ed. J. Connell. Pacific Research Monograph No.24. Canberra: Australia National University.

Connell, J., and Conway, D. 2000. Migration and remittance in Islands microstates: A comparative perspective on the South Pacific and the Carribean. International Journal of Urban and Regional Research 24(1): 53-78.

Evans, M. 2001. Persistence of the gift: Tongan tradition in transnational context. Ontario: Wilfred Laurier University Press.

Faeamani, S. U. 1993. Migrant remittances: The engine of village development in Tonga. Unpublished MA Thesis, James Cook University, Australia.

Faeamani, S. 1995. The impact of remittances on rural development in Tongan villages. Asian and Pacific Migration Journal 4(1): 139-155.

Fensterseifer, C. 1993. Western Samoa's economic development: Contemporary constraints, historical conflicts and new opportunities. New Zealand Journal of Geography 95: 14-18.

Fisi'iahi, F. V. 2001. Migration from Tonga: of more benefits than harm? In Current trends in south Pacific migration, ed. V. Naidu, E. Vasta, and C. Hawksley, 41-53. Asia Pacific Migration Research Network Working Paper No. 7. University of Wollongong, Australia.

Fletcher, M. 1995. Pacific islands peoples in the labor market. Labor Market Bulletin 1: 124-136.

Fuka, M. L. A. 1984. The Auckland Tongan community and overseas remittances. Unpublished MA Thesis, University of Auckland, New Zealand.

Government of Tonga Official Website 2002. http:// www.pmo.gov.to

Government of Tonga Budget Statement. 2002. Budget for the year ended $30^{\text {th }}$ June 2002. Nuku'alofa: Government of Tonga.

Haberkorn, G. 1997. A sea of islands: A myriad of indicators on the interface between demography and planning in the Pacific islands. Asia Pacific Viewpoint 38(3): 219-236.

Hau'ofa, E. 1993. Our sea of islands. In A new Oceania: Rediscovering our seas of islands, ed. E. Waddell, V. Naidu, and E. Hau'ofa, 2-16. A USP $25^{\text {th }}$ anniversary publication. Suva: School of Social and Economic Development, The University of the South Pacific in association with Beake House.

Hayes, G. 1992. The use of scientific models in the study of Polynesian migration. Asian and Pacific Migration Journal 1(2): 278-311.

Hayes, G. 1993a. Polynesian migration and the demographic transition: A missing dimension of recent theoretical models. Pacific Viewpoint 34(1): 1-35

Hayes, G. 1993b. MIRAB processes and development on small Pacific islands: A case study from the southern Massim, Papua New Guinea. Pacific Viewpoint 34(2): 153-178.

Hooper, A. 1993. The MIRAB transitions in Fakaofo, Tokelau. Pacific Viewpoint 34(2): 241-264.

James, K. E. 1991. Migration and remittances: a Tongan village perspective. Pacific Viewpoint 32 (1): $1-23$.

James, K.E. 1998. Pacific islands stakeholder participation in development: Tonga. Pacific islands discussion paper series. Washington: World Bank.

James, K. E. 2002. Disentangling the grass roots in Tonga: Traditional enterprise and autonomy in the moral and market economy. Asia Pacific Viewpoint 43(3): 269-292.

Kishida, Y. 2000. Tonga no kaigai imin to kyokai. Unpublished MA Thesis, Kobe University, Japan.

Laplagne, P. 1997. Dutch disease in the south Pacific: evidence from the 1980s and beyond. Economic Bulletin 12(1): 84-96.

Levick, W., and Bedford, R. D. 1988. Fiji labour migration to New Zealand in the 1980s. New Zealand Geographer 44 (1): 14-21.

Marcus, G.E. 1974. A hidden dimension of family development in the modern Kingdom of Tonga. Journal of Comparative Family Studies 5(1): 87- 
102.

Marcus, G. E. 1981. Power on the extreme periphery: The perspective of Tongan elites in the modern world systems. Pacific Viewpoint 22(1): 48-64.

Marcus, G. E. 1993. Tonga's contemporary globalizing strategies: Trading on sovereignty amidst international migration. In Contemporary Pacific societies: Studies in development and change, ed. V. S. Lockwood, T. G. Harding, and B. T. Wallace, 21-33. New Jersey: Prentice-Hall.

McCall, G. 1996. Clearing confusion in a disembedded world: the case for nissology. Geographische Zeitschrift 84(2): 74-85.

McCall, G. 1997. Nissology: A debate and discourse from below. Invited paper at the cultural heritage in islands and small states Conference. Valletta, Malta, 8-10 May. http://www.arts.unsw. edu.au/southpacific/nissology.htm.

Mohanty, M. 2001. Contemporary emigration from Fiji: Some trends and issues in the postindependence era. In Current trends in south $\mathrm{Pa}$ cific migration, ed. V. Naidu, E. Vasta, and C. Hawksley, 54-73. Asia Pacific Migration Research Network Working Paper No. 7. University of Wollongong, Australia.

Morton, H. 1996. Becoming Tongan: An ethnography of childhood. Honolulu: University of Hawaii Press.

Morton, H. 1998. Creating their own culture: diasporic Tongans. The Contemporary Pacific 10(1): 1-30.

Muliana, T. 2001. Remittances, the social system and development in Samoa. In Current trends in south Pacific migration, ed. V. Naidu, E. Vasta, and C. Hawksley, 20-40. Asia Pacific Migration Research Network Working Paper No. 7. University of Wollongong, Australia.

National Reserve Bank of Tonga. 1999. Annual report 1999/2000.

National Reserve Bank of Tonga. 2000. Quarterly bulletin, December 11 (4).

New Zealand Immigration. 2002a. New Zealand immigration service fact pack, Issue 16. Wellington: New Zealand Immigration.

New Zealand Immigration. 2002b. Migrating to New Zealand: visa categories. http://www/immigration.gov.nz

Poirine, B. 1994. Rent, emigration and unemployment in small islands: The MIRAB model and the French overseas departments and territories. World Development 22(12): 1997-2009.

Poirine, B. 1998. Should we hate or love MIRAB? The Contemporary Pacific 10(1): 65-105.

Secretariat of the Pacific Community. 2001. Population and development planning in the Pacific. Nou- mea, New Caledonia: Demography/Population Programme, Secretariat of the Pacific Community. http://www.spc.int/demog/.

Small, C. A. 1997. Voyages from Tongan villages to American suburbs. Ithaca: Cornell University Press.

Statistics New Zealand. 2001. Population Census. http://www.stats.govt.nz/

Statistics New Zealand. 2002. Pacific progress: A report on the economic status of Pacific peoples in New Zealand. Te Tari Tatau, Wellington: Statistics New Zealand.

Sudo, K. 1997. Expanding international migration by the Tongan people: Strategies and socio-cultural effects on the homeland. In Contemporary migration in Oceania: Diaspora and network, ed. K. Sudo and S. Yoshida, Osaka: The Japan Center for Area Studies, National Museum of Ethnology.

Thomas, F.R. 2002. Self-reliance in Kiribati: Contrasting views of agricultural and fisheries production. The Geographical Journal 168(2): 163177.

Tongamoa, S. T. 1987. Migration, remittance and development: A Tongan perspective. Unpublished MA Thesis, University of Sydney, Australia.

Tonga Statistics Department. 1986. Population census 1986. Bulletin no.1. Nuku'alofa: Statistics Department.

Tonga Statistics Department. 1996. Population census 1996: Administrative Report and General Tables. Nuku'alofa: Statistics Department.

Tonga Statistics Department. 1999. Tonga population census 1996: Household analysis. Nuku'alofa: Statistics Department.

Tonga Statistics Department. 2001. Statistical indicators 2001. Nuku'alofa: Statistics Department.

Treadgold, M. L. 1999. Breaking out of the MIRAB mould: historical evidence from Norfolk island. Asia Pacific Viewpoint 40(3): 235-249.

Trlin, A. D. 1987. New Zealand's admission of Asians and Pacific islanders. In Pacific bridges: The new immigration from Asia and the Pacific islands, ed. J. T. Fawcett and B. V. Carino. New York; Center for Migration Studies.

United States Census Bureau. 2001. Native Hawaiian and other Pacific islander population: 2000. http:/ / www.census.gov / population / www / cen $2000 /$ briefs.html

Va'a, L. F. 1992. The future of Western Samoan migration to New Zealand. Asian and Pacific Migration Journal 1(2): 313-332.

Vaden, B. D. 1998. Kainga: Tongan families as agents of change. Unpublished PhD Dissertation. A Bell and Howell Company, Michigan. 